\title{
Estimation of Bioenergetics Parameters for a Stunted Northern Pikemin- now Population of South Central British Columbia
}

\author{
Nathan Taylor* and Carl Walters
}

Fisheries Centre, University of British Columbia, Vancouver, B.C. V6T $1 Z 4$

\begin{abstract}
We estimate bioenergetics parameters using length-age and mark-recapture data for a stunted population of Northern pikeminnow on the Bonaparte plateau, British Columbia using a seasonal reproduction, skeletal allocation model. We show that using field data alone it was possible to estimate food consumption rates, standard metabolic rate and metabolic $\mathrm{Q}_{10}$ parameters, the proportional increase in feeding rate per $10^{\circ} \mathrm{C}$ increase $\left(\mathrm{Q}_{\mathrm{c}}\right)$, but that prior parameter ranges must be specified. Using the estimated parameter set, we predict body sizes using warmer water temperatures from Cultis Lake, British Columbia and the John Day Reservoir, Columbia River. We show that surface temperature differences between the Bonaparte plateau, John Day reservoir and Cultus Lake alone are insufficient to explain very large under-predictions of body size for these areas. In addition to diet differences, fish are likely choosing between fine-scale temperature and food-density environments to optimize capture and metabolism of food.
\end{abstract}

Keywords: Growth estimation, bioenergetics, Northern pikeminnow, tagging, von Bertalanffy.

\section{INTRODUCTION}

Northern pikeminnow (Ptychocheilus oregonensis) consumption rates of salmonids in the Columbia River, Washington and Cultus Lake, British Columbia have been subject to considerable study [1-3]. In the Columbia river, many studies ultimately led to the development of bioenergetics parameter sets in order to estimate the magnitude of predation effects (reviewed in Petersen et al. [4]). With declining salmon runs in these areas, determining the magnitude of Northern pikeminnow salmonid predation and mediating it have been serious concerns in both Cultus lake $[1,2]$ and Columbia river cases [5-10]. The objective of these studies was to estimate bioenergetics parameters [11-13], then use diet fraction to characterize in-river consumption rates of juvenile salmon by Northern pikeminnow, and ultimately to determine population level impacts of this consumption on endangered salmon populations under future climate regimes [7] or predator removal scenarios [5].

Bioenergetics models have been used for estimating total prey consumption of Northern pikeminnow and temperaturechange effects on that consumption [14]. However the ability of such models to address fish management questions depends on reasonable agreement between field observations and model predictions of growth and consumption rates. Disagreement between observed and predicted rates can be caused by inaccuracies in field measurements, bioenergetic parameter estimates or both. Reasons for the differences have been well studied [15] and discrepancies between predicted and observed consumption rates (based on stomach contents) can be large [16]. Many studies rely on extrapolation from laboratory to field values for specific cases. Corre-

*Address correspondence to this author at the Fisheries Centre, University of British Columbia, Vancouver, B.C. V6T 1Z4; Tel: 604-822-6348; Fax: 604-822-8934; E-mail: n.taylor@fisheries.ubc.ca sponding estimates of activity and in particular, consumption rates can be systematically biased in cases where there are diet [17] or behavioral [18] differences.

Field tests of bioenergetic studies reveal relatively poor agreement between field observations and model predictions of bioenergetics rates [19]. Of the studies reviewed by Chipps et al. [19], the percent difference between observed and predicted food consumption rates varied between $-84 \%$ and $770 \%$ with the majority ( $82 \%$ ) of the studies overestimating consumption rates. Most studies measured consumption rates, only one [20] predicted growth and compared that with field measurements [19]. In addition, many consumption rate estimates rely on assumptions that population level parameter estimates can be used for different, possibly distinct sub-populations. In those cases where a particular subpopulation has different bioenergetics parameter values, then assumptions about corresponding consumption rates for predation studies will be incorrect.

Northern pikeminnow on the Bonaparte Plateau of South Central British Columbia, Canada [21] might be expected to have bioenergetics parameters different from those estimated from other populations from lower elevation, warmer water bodies. In the Bonaparte area, Northern pikeminnow have asymptotic sizes half to a third of those in other areas [21]. Here we use mark-recapture and length-age data collected from the field $[1,22]$ to test whether or not these body size differences come from fundamentally different physiology, or simply from colder and more restricted growing seasons. We compare these estimates to those derived from laboratory estimates of the Wisconsin model parameters developed for the Columbia River fish [4], and we use estimated bioenergetics parameter values to predict body sizes in warmer temperature regimes to determine whether the underlying reason for stunted sizes of Bonaparte plateau pikeminnow is temperature effects alone. 


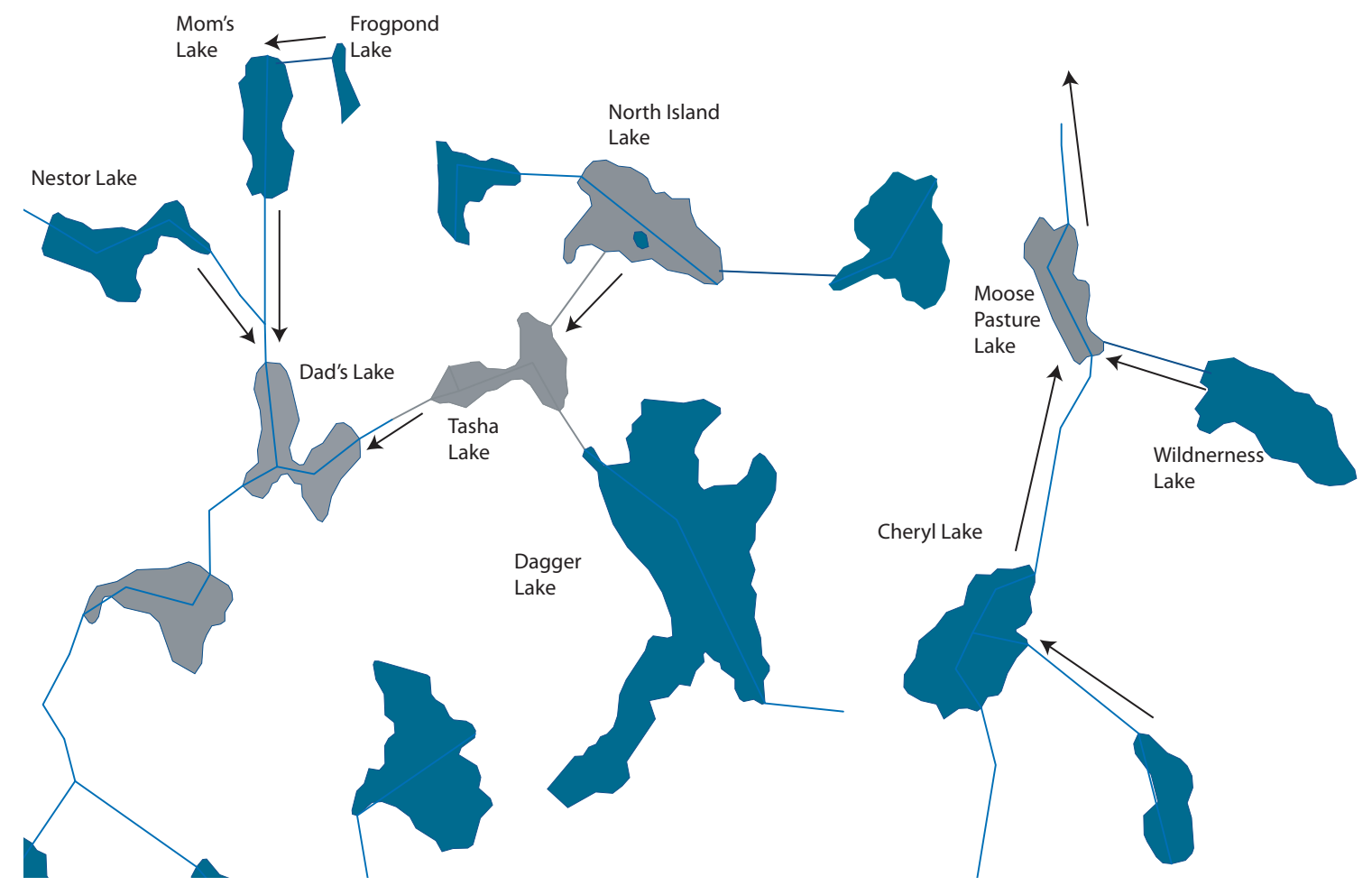

Fig. (1). Map of the Bonaparte Plateau study area in central British Columbia. Arrows indicate direction of stream flow and grey coloring indicates those lakes identified as having fry. Moose Pasture, Wildnerness and Cheryl lakes drain into the Thompson River and the others into the Deadman River.

\section{METHODS}

The Bonaparte plateau is approximately $100 \mathrm{~km}$ North of Kamloops British Columbia, Canada. The study system consists of two drainages. One drains into the Thompson River and another into the Deadman River. Thompson drainage lakes in this study are Cheryl, Moose Pasture, and Wilderness Lakes. Deadman drainage lakes were Dad's, Mom's, and Nestor lakes (Fig. 1).

Bonaparte Plateau lakes all freeze over winter, with iceon starting late September to mid-October. Ice-off occurs generally mid to late May. Temperatures were sampled in the middle of each lake every two weeks from June $1^{\text {st }}$ until ice-on from 2001-2005. Maximum mid-lake summer temperatures rarely exceeded $20 \mathrm{C}^{\mathrm{O}}$ and there was a very short growing season (2-4 months) when temperatures are above $4 C^{\circ}$. We used observed data in Dad's and Moose Pasture lakes to derive a smoothly varying sinusoidal function for lake surface temperature, averaged over years and lakes (Fig. 2).

\section{Parameter Estimation}

We use the likelihood derivation of Walters and Essington [22] to estimate bioenergetics parameters from lengthage and mark-recapture data. We provide an overview of the model here but readers should consult that reference for details. All variable and parameter symbols are listed in Appendix A and B. The basic model for fish changes in weight per unit time is

$$
\mathrm{dW} / \mathrm{dt}=H W^{\mathrm{d}} \mathrm{f}_{\mathrm{c}}(\mathrm{T}(\mathrm{t}))-\mathrm{mW}^{\mathrm{n}} \mathrm{f}_{\mathrm{m}}(\mathrm{T}(\mathrm{t}))
$$

where $\mathrm{W}$ is body weight and $\mathrm{H}, \mathrm{d}, \mathrm{m}$, and $\mathrm{n}$ are aggregated bioenergetics parameters for feeding and metabolism. Relative food consumption $f_{c}$ and metabolism $f_{m}$ are functions of temperatures $T$ experienced at time $t$ by individual fish. We model these as:

$$
\begin{aligned}
& f_{c}(T)=Q_{c}{ }^{(T-10) / 10} e^{-g(T-T m)} /\left(1+e^{-g(T-T m)}\right) \\
& f_{m}(T)=Q_{m}{ }^{(T-10) / 10}
\end{aligned}
$$

Here, $\mathrm{Q}_{\mathrm{m}}$ and $\mathrm{Q}_{\mathrm{c}}$ are $\mathrm{Q}_{10}$ coefficients, typically around 2.0 for $\mathrm{Q}_{\mathrm{m}}[23]$ and often much larger for $\mathrm{Q}_{\mathrm{c}}$ since $\mathrm{Q}_{\mathrm{c}}$ typically represents the increase with $\mathrm{T}$ in both digestion rates and food availability. $\mathrm{H}$ and $\mathrm{m}$ represent feeding and metabolic rates at $\mathrm{T}=10$ degrees $\mathrm{C}$ ). The exponential ratio in eq. (14) represents the drop in feeding at high temperatures; $T_{m}$ represents the temperature at which feeding rate drops to half the value predicted from $Q_{c}$, and $g$ represents how rapidly feeding drops off as $T_{m}$ is approached.

Most Northern pikeminnow length-age and markrecapture data consisted of fish at, or approaching maturity. Beamsderfer 1992 [24] shows that $75 \%$ of males are mature by age 3 whereas $75 \%$ females are mature at age 6 . We did not distinguish between male and female fish in this analysis but we assume that sampled fish make seasonal allocation of energy into gonadal tissues. We then estimate bioenergetics parameters using the more complex seasonal reproduction, skeletal allocation (SRSA) [22] (equations 17-19) of Walters and Essington. Here we partition body weight $\mathrm{W}$ into two components, structural weight $\mathrm{W}_{\mathrm{s}}$ and metabolizable weight $\mathrm{W}-\mathrm{W}_{\mathrm{s}}$. Then the dynamics of $\mathrm{W}_{\mathrm{s}}$ can be represented by the 


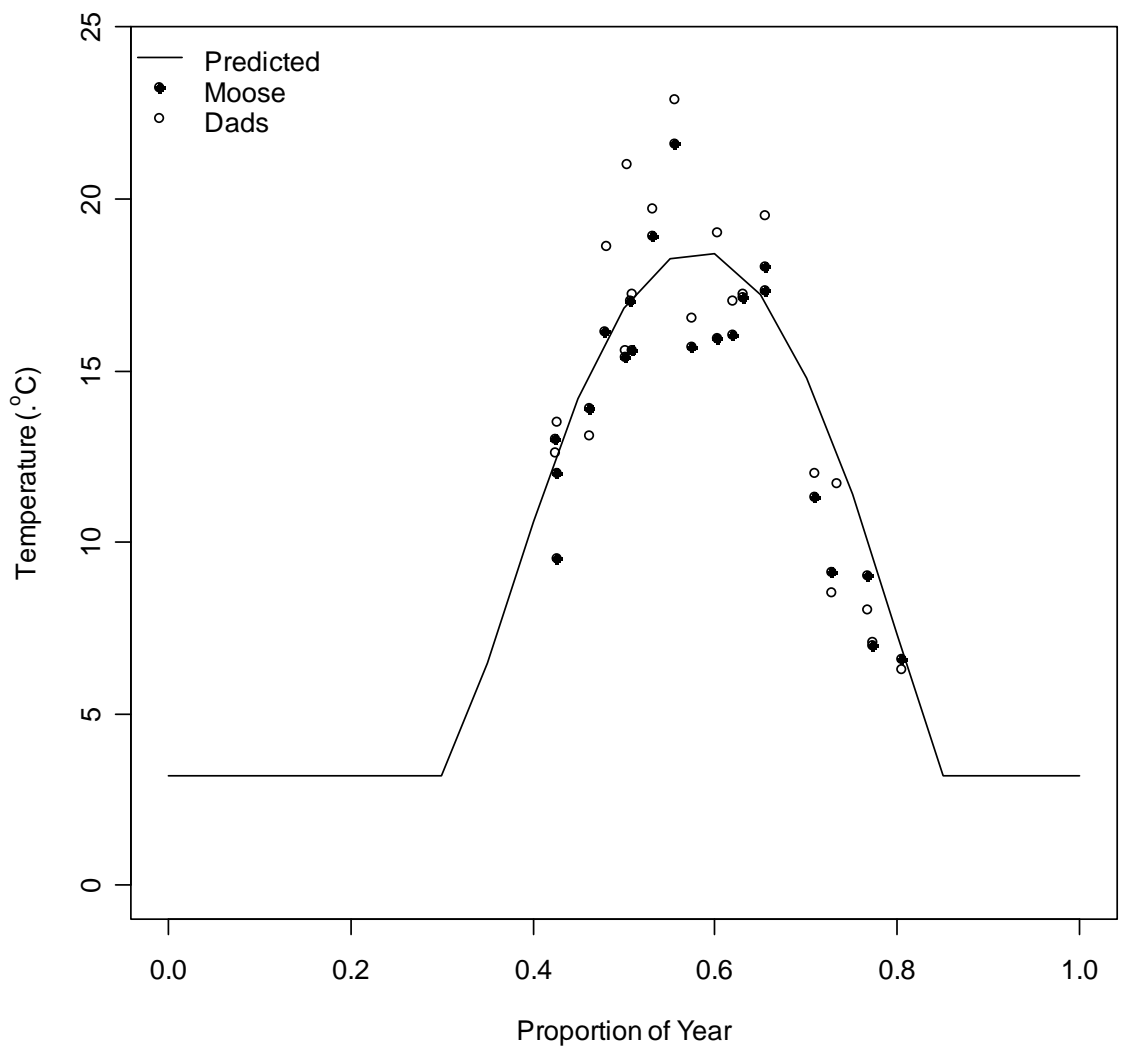

Fig. (2). Observed temperatures for Moose and Dad's lakes, with corresponding sin curve fit.

Jones et al. [25] assumption that a proportion $\mathrm{f}_{\mathrm{s}}$ of total growth rate is allocated to $\mathrm{W}_{\mathrm{s}}$ as:

$$
\mathrm{dW}_{\mathrm{s}} / \mathrm{dt}=\mathrm{f}_{\mathrm{s}} \mathrm{eR}=\mathrm{f}_{\mathrm{s}} \mathrm{H}^{\prime} \mathrm{W}_{\mathrm{s}}^{\mathrm{d}}
$$

where a fraction of net food intake $f_{s}$ is allocated to structural growth, whether or not body weight is growing and $\mathrm{H}^{\prime}=\mathrm{H} / \mathrm{f}_{\mathrm{s}}^{\mathrm{d}}$ where $\mathrm{f}_{\mathrm{s}}$ is the "normal" ratio of $\mathrm{w}_{\mathrm{s}}$ to $\mathrm{w}$. Here $\mathrm{f}_{\mathrm{s}}$ is made a decreasing function of total body weight even when there are no disturbances such as release of eggs, according to some function of the general form so that fish do not become progressively thinner with age [22].

$$
\mathrm{f}_{\mathrm{s}}=\mathrm{f}_{\mathrm{s}}\left(1-(\mathrm{m} / \mathrm{H}) \mathrm{W}^{\mathrm{n}-\mathrm{d}}\right)
$$

We model adjustments in $\mathrm{f}_{\mathrm{s}}$ when predicted $\mathrm{W}_{\mathrm{s}} / \mathrm{W} \neq \mathrm{f}_{\mathrm{s}}$ by multiplying $\mathrm{f}_{\mathrm{s}}$ at each moment (or the weight-adjusted $\mathrm{f}_{\mathrm{s}}$ [22] eq. 18) by a feedback function $\mathrm{f}_{\mathrm{s}}=\mathrm{f}_{\mathrm{s}} \mathrm{C}\left(\mathrm{W}_{\mathrm{s}}, \mathrm{W}\right)$, where $\mathrm{C}=1$ for $\mathrm{W}_{\mathrm{s}} / \mathrm{W}=\mathrm{f}_{\mathrm{s}}$ and varies with "thinness" $\mathrm{W}_{\mathrm{s}} / \mathrm{W}$ as

$$
\mathrm{C}\left(\mathrm{W}_{\mathrm{s}}, \mathrm{W}\right)=2 /\left(1+\exp \left(-\theta\left(\mathrm{f}_{\mathrm{s}} \mathrm{W}-\mathrm{W}_{\mathrm{s}}\right)\right)\right)
$$

Here $\mathrm{C}$ is a logistic function that sets $\mathrm{C}$ to be a maximum of 2. and drops $\mathrm{C}$ towards 1 as $\mathrm{Ws} / \mathrm{W}$ approaches $\mathrm{f}_{\mathrm{s}}{ }_{\mathrm{s}}$ with steepness set to $\theta[22]$.

We assume that individual variation in feeding rates, and hence in individual asymptotic sizes $\mathrm{L}_{\infty}$, can be represented as a multiplicative departure $R_{i}$ of individual i's size at age from the population mean size, i.e. $\mathrm{L}_{\mathrm{i} 1}=\bar{L}\left(a_{1 i}\right) \mathrm{R}_{\mathrm{i}}$, plus a measurement error, $\mathrm{L}_{\mathrm{i} 2}=\bar{L}\left(a_{1 i}+\Delta t_{i}\right) \mathrm{R}_{\mathrm{i}}$. Here $\mathrm{a}_{1 \mathrm{i}}$ is the age of fish $\mathrm{i}$ at tagging (an integer year plus deviation of capture date from date when $\mathrm{a}=0 . \bar{L}(a)$ is the population mean growth function, dependent on length at first modeled age 0 and on all the parameters $(\mathrm{H}, \mathrm{m}, \mathrm{Q} 10$ 's, etc.) used to predict mean length over time and age. Assuming normally distributed, independent measurement errors with variance $\sigma_{m}^{2}$ and normally distributed sample $\mathrm{R}_{\mathrm{i}}$ with mean 1.0 and variance $\sigma_{R}^{2}$, it is easily seen that the maximum likelihood estimate of $R_{i}$ given any assumed age $a_{1 i}$ is given by

$$
\begin{aligned}
& \hat{\mathrm{R}}_{i}\left(a_{1 i}\right)=\left[\bar{L}\left(a_{1 i}\right) \mathrm{L}_{\mathrm{i} 1}+\bar{L}\left(a_{1 i}+\Delta t_{i}\right) \mathrm{L}_{\mathrm{i} 2}+\sigma_{m}^{2} / \sigma_{\mathrm{R}}^{2}\right] /\left[\bar{L}\left(a_{1 i}\right)^{2}\right. \\
& \left.+\bar{L}\left(a_{1 i}+\Delta t_{i}\right)^{2}+\sigma_{m}^{2} / \sigma_{\mathrm{R}}^{2}\right]
\end{aligned}
$$

This estimate of $\mathrm{R}$ is just the weighted average of the two $\mathrm{L} / \bar{L}$ observations, but corrected toward 1.0 in cases where $\sigma_{R}^{2}$ is assumed small compared to the measurement variance. The log-likelihood of each $\mathrm{L}_{\mathrm{i} 1}, \mathrm{~L}_{\mathrm{i} 2}$ observation $\mathrm{i}$ given this maximum likelihood estimate of $R_{i}$ is then proportional to (ignoring constant terms shared by all observations)

$$
\begin{gathered}
\ln L_{\mathrm{i}}\left(\mathrm{a}_{1 \mathrm{i}}\right)=-\left[\left(\hat{\mathrm{R}}_{i}\left(a_{1 i}\right) \bar{L}\left(a_{1 i}\right)-\mathrm{L}_{\mathrm{i} 1}\right)^{2}+\left(\hat{\mathrm{R}}_{i}\left(a_{1 i}\right)\right.\right. \\
\left.\left.\bar{L}\left(a_{1 i}+\Delta t_{i}\right)-\mathrm{L}_{\mathrm{i} 2}\right)^{2}\right] / \sigma_{\mathrm{m}}^{2}-\left(\hat{\mathrm{R}}_{i}\left(a_{1 i}\right)-1.0\right)^{2} / \sigma_{\mathrm{R}}^{2}
\end{gathered}
$$

We calculated the measurement error variance by examining all fish in the database measured one day or less apart, then computing the root mean squared difference between the two measurements. For northern pikeminnow mark- 
recapture data, the mean difference was surprisingly large, around $8 \mathrm{~mm}$.

\section{Data and Fitting}

We collected length-age data from three Bonaparte plateau lakes during three separate depletion experiments in Mom's and Cheryl lakes June and July of 2001, and in Moose Pasture lake August and September 2002. Additional sampling of Dad's lake was done in September 2003. Fish were captured using gillnets for depletions in Mom's and Cheryl lake in 2001 and using fyke nets for Moose Pasture and Dad's lakes. For the purpose of this analysis we were interested in population characteristics at large scale, so we combined otolith and mark-recapture data across all lakes/years.

In total, we took 2621 pairs of Lapilli otoliths, and aged one otolith from each pair by cutting each otolith through the dorsal ventral axis, then burning and counting rings from the centroid. A total of 1082, 263, 945, and 284 otoliths were aged from Dad's, Mom's Moose Pasture and Cheryl Lakes respectively. Failing to correctly section otoliths from fish greater than 5 years old likely resulted in common under aging.

Fish from the Fyke net sampling were tagged whenever practical, leading to 2032 tag recoveries separated by more than two weeks from tagging. Tag recoveries were divided into two groups - within season recoveries (typically made between June and September) and between season recoveries (from summer to summer). Integer ages determined from counting were adjusted to reflect the time of the year that samples were collected so that the ages used in the model were the estimated otolith age plus the year fraction of the date with the otolith was collected.

The total data set contained both over-summer and fall to early summer tag recoveries of 2032 fish, plus large sample of fish aged by otoliths (2621 fish) of which 181 fish were also tag recoveries. These 181 fish allowed comparison of otolith age to the estimated age determined by maximizing eq. (7) above with respect to age.

Summing maximum likelihoods from eq. (7) with respect to age over all fish $i$ represents a likelihood function for the tagging data:

$$
\ln L=\sum_{i} \max _{a 1_{i}}\left[\ln L_{i}\left(a_{1 i}\right)\right]
$$

To this we added a likelihood component for the lengthage sample $\mathrm{j}=1 \ldots 2621$ fish:

$$
-\sum_{\mathrm{j}=1}^{\mathrm{n}}\left[\left(\mathrm{L}_{\mathrm{j}}-\overline{\mathrm{L}}\left(\mathrm{a}_{\mathrm{j}}\right)\right)^{2} /\left(\sigma_{\mathrm{D}} \overline{\mathrm{L}}\left(\mathrm{a}_{\mathrm{j}}\right)\right)^{2}+\ln \left(\sigma_{\mathrm{D}} \overline{\mathrm{L}}\left(\mathrm{a}_{\mathrm{j}}\right)\right)\right]
$$

Using the combined likelihood function (eq 8 plus eq. 9), it was not possible to freely estimate, $m, d, n, Q_{m}, \Theta$ and $\mathrm{W}_{\infty}$. Instead, we needed to assume uniform priors for these parameters. Parameter starting values and bounds are listed in Appendix B. Four MCMC chains were run with different initial values for 500,000 iterations, with a burn-in of 2,000 iterations. We took 2000 samples of the chains to visualize posteriors and parameter correlations.

We use bioenergetics parameters estimated from Bonaparte plateau data to make predictions of expected Bonaparte pikeminnow grow in different temperature environments. Using estimated bioenergetics parameter values we ran the model forward under temperature profiles from the John Day reservoir, Nevada and Cultus Lake, BC. We drive the predictions using reported Cultis Lake and John Day temperatures.

\section{RESULTS}

For the few observations we had of fish that were both aged and tagged, we show that conditional maximum likelihood estimate of ages derived from the SRSA model are consistent with observed otolith ages (Fig. 3A). In addition, relative fish numbers tagged at age show strong sampling bias toward fish large enough to be tagged (Fig. 3B). Also, absence of sampled fish numbers in smaller age classes for otolith samples reflect gear selectivity effects. Overwinter vs. summer growth increments from tagging show that cold winter temperatures virtually stop northern pikeminnow growth in the Bonaparte Lakes (Fig. 4A). Fish that experienced higher mean temperatures over the mark-recapture interval showed the highest growth increments (Fig. 4B). Bonaparte plateau Northern pikeminnow show von Bertalanffy type growth, with declining growth increments as a function of apparent age (Fig. 4C).

SRSA bioenergetics model fits support direct observations that Bonaparte plateau northern pikeminnow stop growing in length over cold winter months (Fig. 5). In addition to winter weight loss, the model predicted that as fish reached maturity, early season weight increases were followed by weight losses and decreases in condition factor corresponding to gonadal tissues energy allocation (Fig. 6).

Estimates of $\mathrm{H}$ and $\mathrm{Q}_{10}$ parameters were uncertain with broad posterior distributions (Fig. 7). There were strong correlations between some parameters estimates (Table 1). In particular net food consumption and standard metabolic rates (correlation coefficient 0.9 ) as well as the food consumption and metabolism power parameter estimates ( $d$ and $n$ ) were highly correlated (confounded). In these cases, body-size data alone do not contain enough information to disentangle consumption and metabolic effects (i.e. fish got large because of high caloric intake rates and high metabolism, or else because of low rates of intake combined with low metabolism).

Temperature differences alone do not completely explain regional differences in northern pikeminnow body sizes. When temperature data from Cultus Lake and John Day reservoirs are used to drive the model with estimated Bonaparte Plateau pikeminnow parameters, the model predicts much larger body sizes (Fig. 8). However, it under-predicts observed lengths in those warmer systems by a significant margin. When driven with Cultus Lake temperatures, the model predicts asymptotic sizes nearly $100 \mathrm{~cm}$ smaller than observed. For John Day reservoir, the model under-predicts asymptotic body size by nearly $200 \mathrm{~cm}$. 

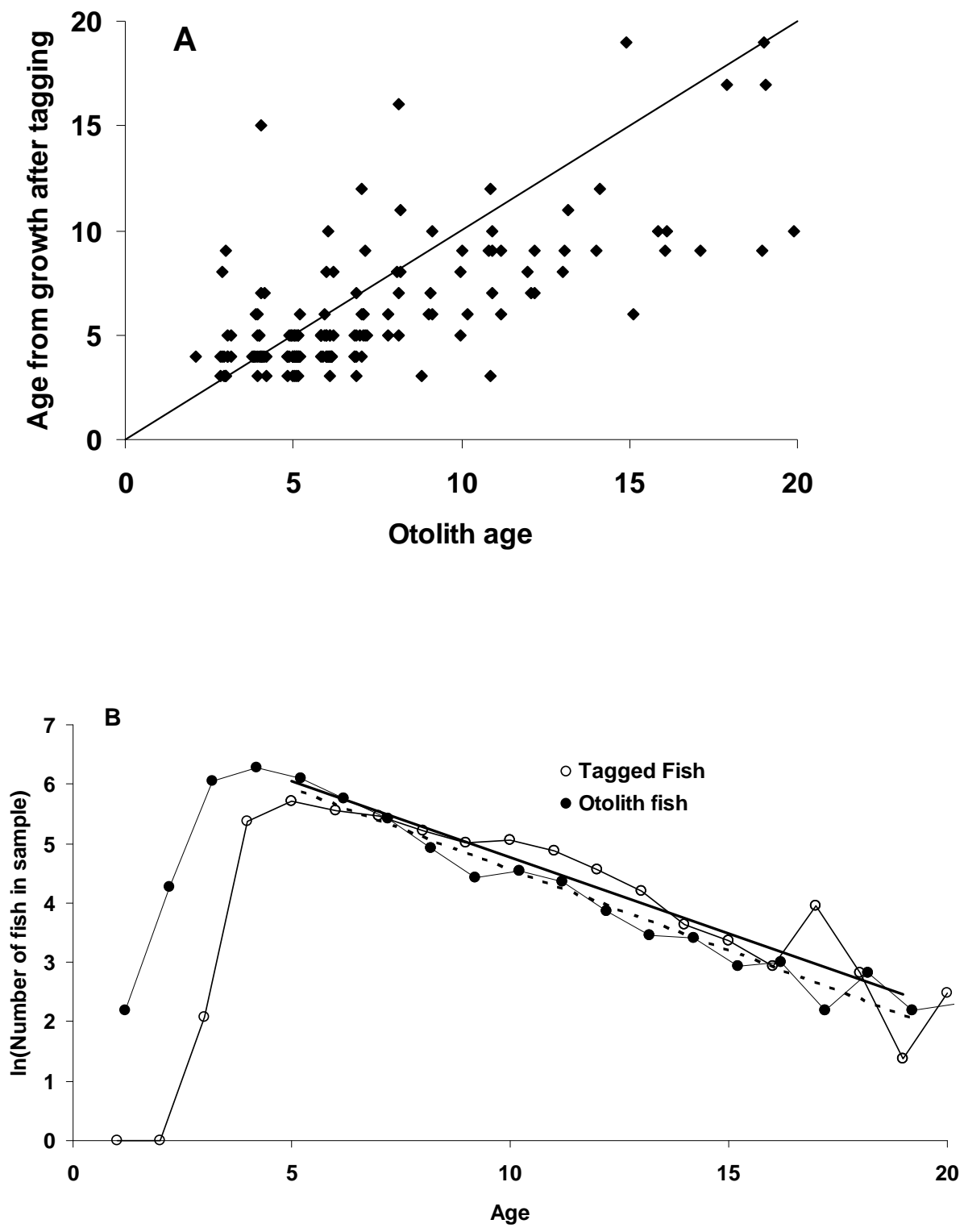

Fig. (3A). A) Predicted age from growth after tagging and B) Log of fish number sampled vs. age.

\section{DISCUSSION}

Prior information on some parameters was needed to estimate Northern pikeminnow bioenergetics parameters from field data. In addition to at least one of the $\mathrm{Q}_{10}$ parameters, priors estimates for the: metabolism power parameter (n), food consumption power parameter (d), asymptotic weight $\left(\mathrm{W}_{\infty}\right)$ and slope parameter for decreasing allocation to structural tissue as $\mathrm{W} / \mathrm{W}$ varies around $\mathrm{f}_{\mathrm{s}}{ }_{\mathrm{s}}$ were also needed. This means that additional information from laboratory studies or other species is needed in order to supplement bioenergetics parameter estimation using field data.

Some aspects of diet and consumption are not accounted for using temperature alone i.e. that pikeminnow in Cultus Lake and John Day Reservoirs must consume more, richer prey in order to achieve observed body sizes ( $\mathrm{H}$ must be larger), given the same bioenergetics parameters for metabolism and size allometry. Walters and Essington (this issue) suggest that under-predictions in size-at-age using the Bona- parte bioenergetics parameter set are due to prey-energycontent differences between Bonaparte plateau lakes and juvenile salmon rich diets available in the John Day reservoir and Cultus lake systems. This is almost certainly the case but even using bioenergetics parameters specifically derived assuming salmon consumption [4], the ratio of model to field observed rates of consumption were consistently underpredicted. Underestimates of Northern pikeminnow food consumption rate using bioenergetics models are anomalous in this respect. In $82 \%$ of bioenergetics studies conducted since 1980 , food consumption was actually overestimated [19].

Our analyses show that if growing seasons were longer and/or warmer then fish could grow considerably larger, given the same prey energy densities. However, it is likely that prey energy fields and temperatures represented in the $\mathrm{H}$ parameter do not reflect actual environment(s) experienced by wild northern pikeminnow. Rather than experiencing stea- 

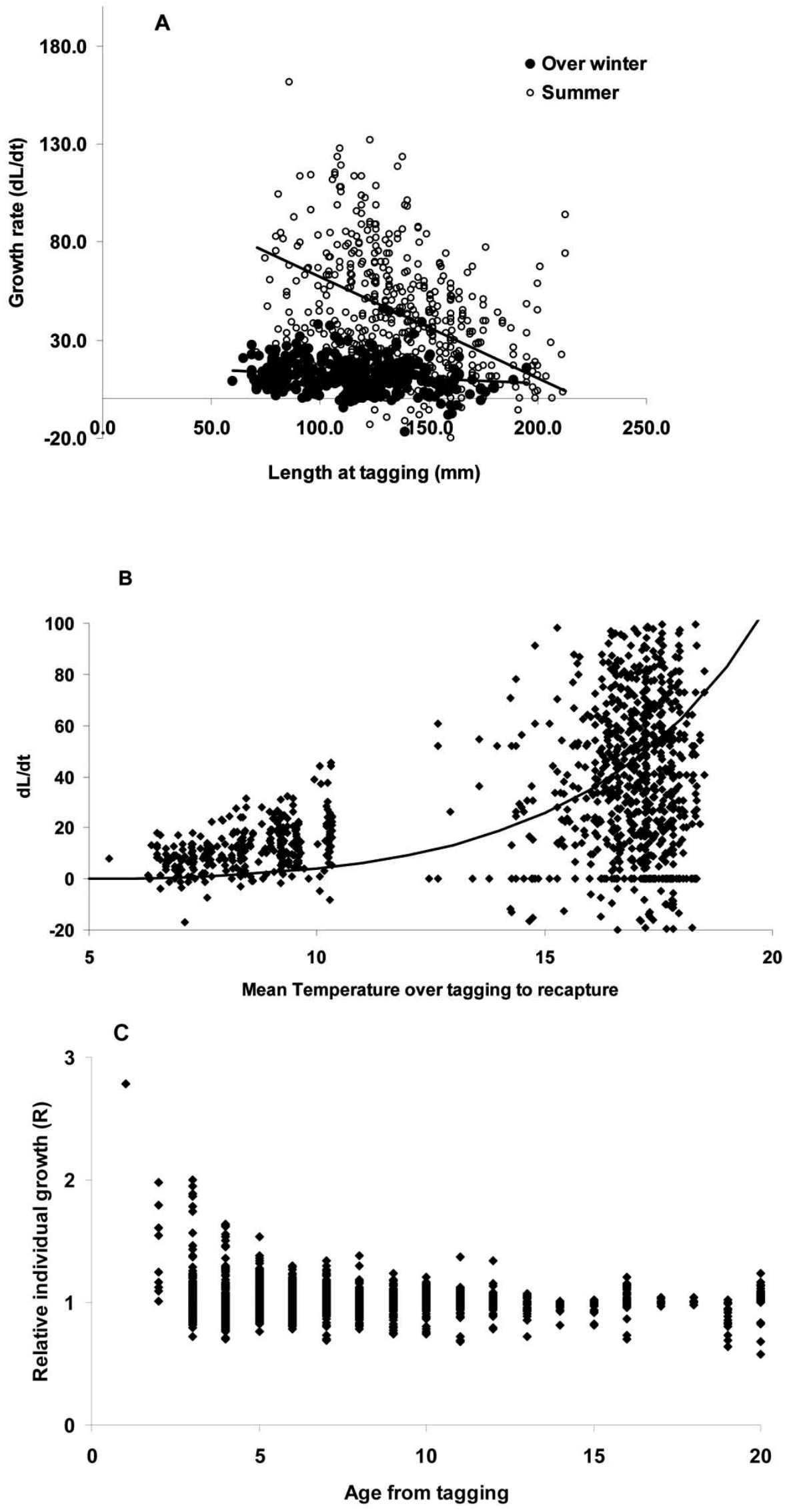

Fig. (4). A) Relative growth rates (dL/dt) fish that were marked and recaptured between fall and spring (overwintered) and those marked in the spring and recapture before fall. B) dL/dt vs. mean temperature over tagging to recapture and C) Relative individual growth rates vs. age. 


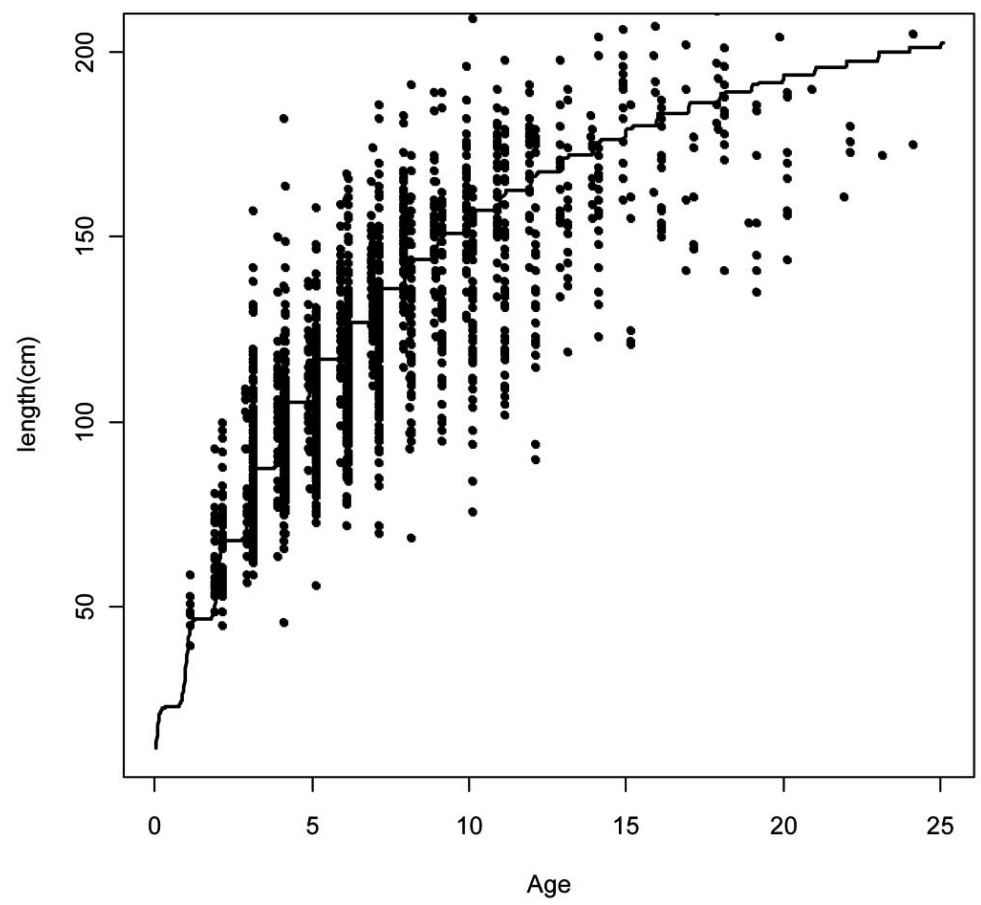

Fig. (5). Predicted (solid line) and observed (dots) length at age.
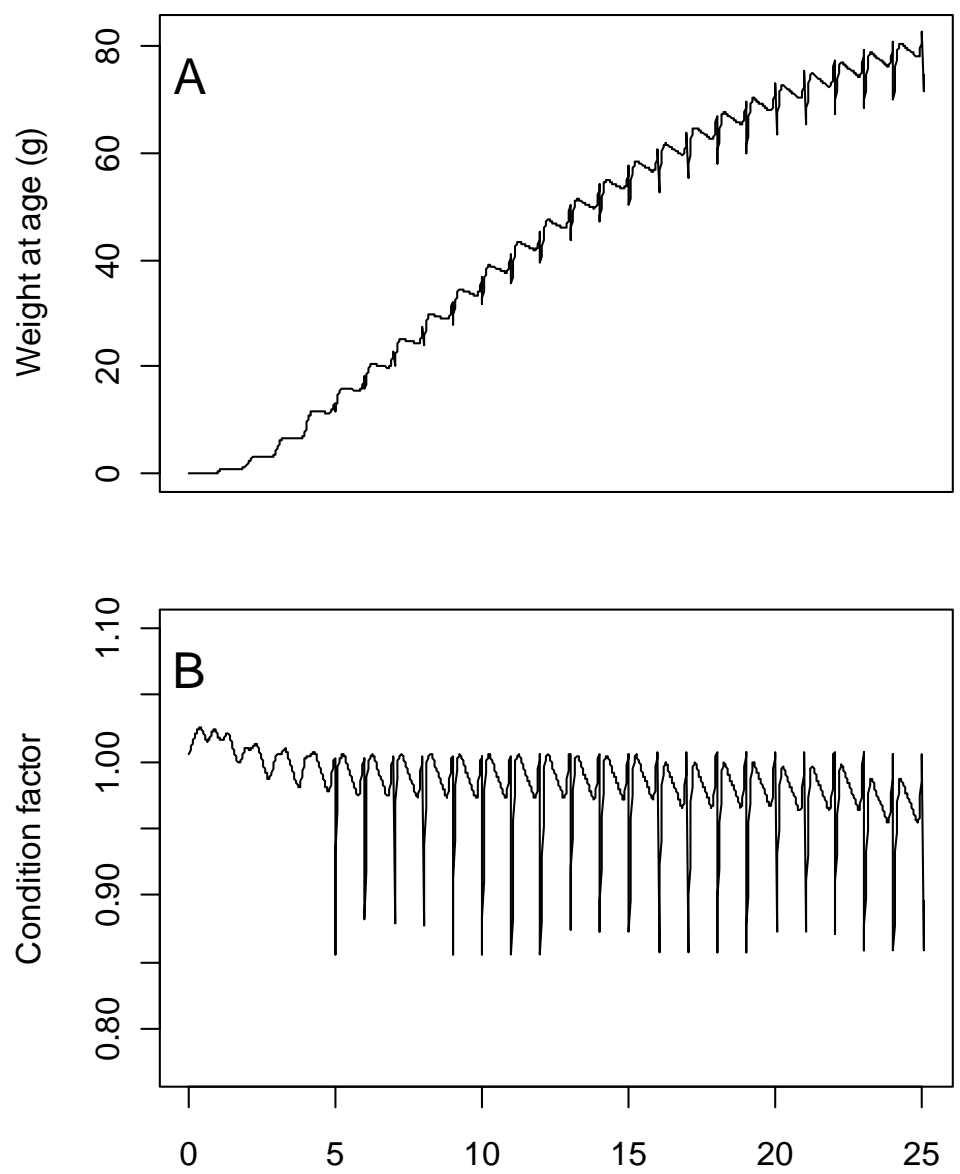

Age (years)

Fig. (6). A) Predicted weight at age (g) and B) predicted condition factor. 


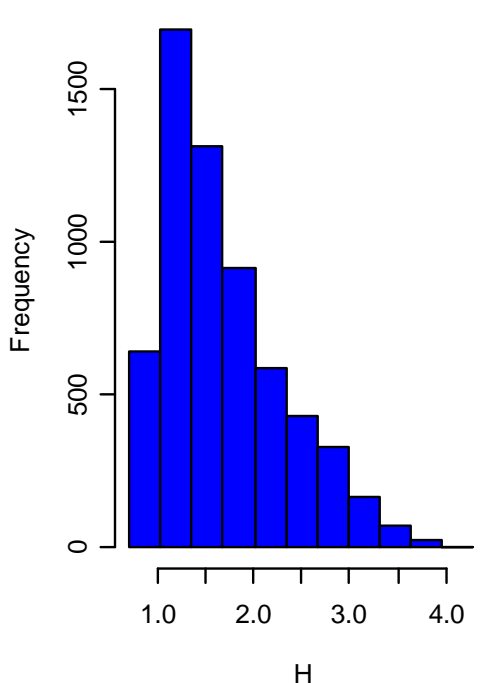

$\mathrm{H}$

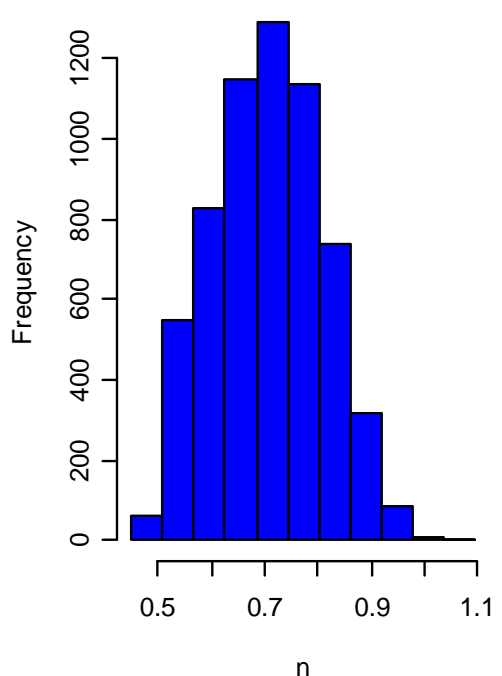

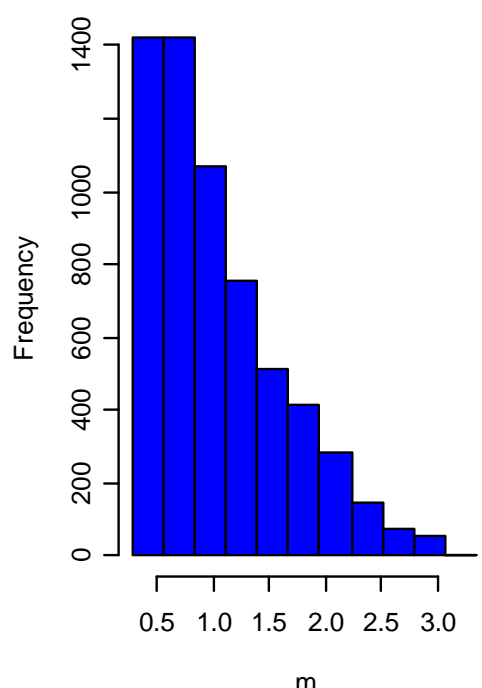

m

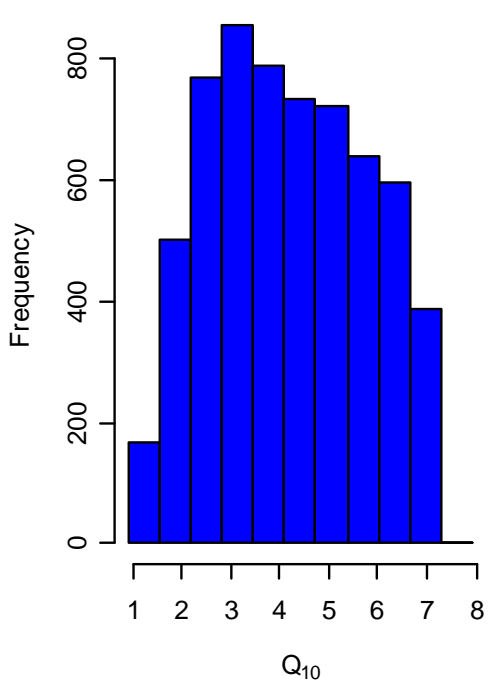

Fig. (7). Histograms of posterior parameters samples. Note R and W omitted, because they were not allowed to vary across a significant range.

Table 1. Posterior Parameter Correlations

\begin{tabular}{|c|c|c|c|c|c|c|}
\hline & $\mathbf{H}$ & $\mathbf{m}$ & $\mathbf{d}$ & $\mathbf{N}$ & $\mathbf{Q}_{\mathbf{1 0}}$ & $\mathbf{Q}_{\mathbf{1 0}}$ \\
\hline \hline $\mathrm{H}$ & 1 & 0.94 & 0.028 & -0.26 & 0.042 & -0.67 \\
\hline $\mathrm{m}$ & - & 1 & -0.10 & -0.41 & 0.20 & -0.42 \\
\hline $\mathrm{d}$ & - & - & 1 & 0.88 & 0.15 & -0.15 \\
\hline $\mathrm{N}$ & - & - & - & -0097 & 1 & -0.030 \\
\hline $\mathrm{Q}_{10}$ & - & - & - & - & - & 0.52 \\
\hline $\mathrm{Q}_{10 \mathrm{c}}$ & - & - & - & & 1 \\
\hline
\end{tabular}




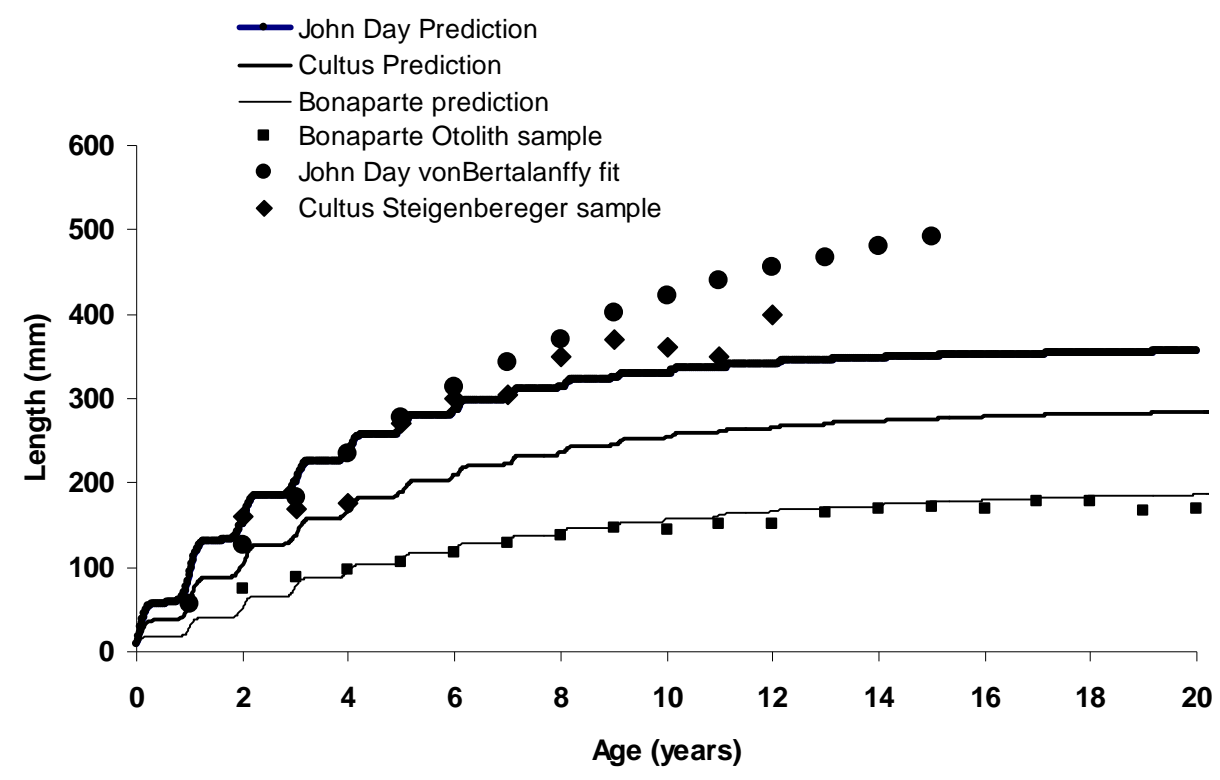

Fig. (8). Projected and observed pikeminnow lengths using estimated Bonaparte plateau bioenergetics parameter values, but observed temperatures for the Cultus and John Day systems.

dily fluctuating, seasonal temperature regimes as modeled here, fish are actively navigating complex suites of smallscale temperature environments, and can seek prey densities that are optimal for particular behavioral modes. For example, Northern pikeminnow may exploit optimal fine-scale environments for prey capture (i.e. optimal swimming performance), consumption rates and may then spend time resting in areas having optimal scope for growth.

The dependence of Northern pikeminnow growth on temperature should serve as a warning for those attempting to estimate von Bertalanffy growth parameters using markrecapture data and traditional statistical approaches such as the Fabens method [26]. For most of these methods, observed sizes at recapture are fit to predicted size at recapture given estimated growth parameters and some known time interval $\Delta t$ to recapture. If fish are captured and released over periods of time where there is limited, or no potential for growth (cold temperature in winter for example), then estimated von Bertalanffy parameters will be biased. Without correcting for such seasonal effects, aggregated seasonal samples could contain an apparent group of fish with slow growth (marked and recaptured over the winter), and another with fast growth (marked and recaptured over the summer). Such considerations are not limited to mark-recapture data, and apply to size-at-age data as well; if there is strong growth dependence on temperature, there will be significant differences between observed sizes at age at the beginning of summer, vs. at the end of summer.

For Northern pikeminnow, estimating bioenergetics parameter values using field data might help alleviate poor predictive ability of models based purely on lab-based studies [4]. However, laboratory studies are still required because, at least in the Bonaparte northern pikeminnow case, field data alone do not contain enough information to estimate all bioenergetics parameters. Using laboratory estimated parameters as prior distributions in the estimation procedure for field data might provide a simpler resolution to poor predictive capacity of purely lab based estimates.

\section{ACKNOWLEDGEMENTS}

Funding was provided by the Pew Foundation, the National Science and Engineering Council of Canada, and the Habitat Conservation Trust Fund of the Province of British Columbia. We would like to thank excellent field and laboratory help in the collection and ageing of fish otolith and to Shayne MacClelland of the Pacific Biological Station, Nanaimo, BC for her assistance in properly ageing northern pikeminnow otoliths.

Appendix A. Variable Symbols and Units

\begin{tabular}{|c|c|c|}
\hline Symbol & Definition & Units \\
\hline \hline $\mathrm{W}$ & Body weight & $\mathrm{G}$ \\
\hline $\mathrm{H}$ & Net food consumption rate per $\mathrm{W}^{-\mathrm{d}}$ & $\mathrm{g} \mathrm{g}^{-\mathrm{d}} \mathrm{yr}^{-1}$ \\
\hline $\mathrm{d}$ & Food consumption power parameter & -- \\
\hline $\mathrm{m}$ & Standard metabolic rate per $\mathrm{W}^{-\mathrm{n}}$ & $\mathrm{g} \mathrm{g}^{-1} \mathrm{yr}^{-1}$ \\
\hline $\mathrm{n}$ & Metabolism power parameter & -- \\
\hline $\mathrm{C}_{\max }$ & Maximum food consumption rate per $\mathrm{W}^{-\mathrm{d}}$ & $\mathrm{gg-d} \mathrm{yr-1}$ \\
\hline
\end{tabular}


Appendix A. contd...

\begin{tabular}{|c|c|c|}
\hline Symbol & Definition & Units \\
\hline $\mathrm{e}$ & Efficiency of food conversion (assimilation x 1-SDA) & -- \\
\hline $\mathrm{R}$ & Feeding rate (ration) & $\mathrm{g} \mathrm{yr}^{-1}$ \\
\hline $\mathrm{W}_{\infty}$ & Maximum body weight & $\mathrm{g}$ \\
\hline$\alpha$ & Anabolic coefficient for length growth & $\mathrm{mm} \mathrm{mm}^{-\delta} \mathrm{yr}^{-1}$ \\
\hline$\delta$ & Power coefficient for anabolic term in length growth & -- \\
\hline$\kappa$ & Metabolic coefficient for length growth & $\mathrm{mm} \mathrm{mm}^{-\eta} \mathrm{yr}^{-1}$ \\
\hline$\eta$ & Power coefficient for metabolism in length growth & -- \\
\hline $\mathrm{L}_{2}$ & Measured body length at recapture & $\mathrm{mm}$ \\
\hline$\Delta \mathrm{t}$ & Time between tagging and recapture & Yr \\
\hline$\sigma_{\mathrm{m}}^{2}$ & Measurement variance for $\mathrm{L}_{1}$ and $\mathrm{L}_{2}$ & $\mathrm{~mm}^{2}$ \\
\hline$\sigma_{\mathrm{L}}^{2}$ & Variance in individual maximum body lengths & $\mathrm{mm}^{2}$ \\
\hline $\ln \mathrm{L}$ & Log likelihood function for parameter estimation & -- \\
\hline $\mathrm{V}$ & Variance of an observed growth increment $\mathrm{L}_{2}-\mathrm{L}_{1}$ & $\mathrm{~mm}^{2}$ \\
\hline $\mathrm{D}$ & Deviation between predicte and observed $\mathrm{L}_{2}$ & $\mathrm{~mm}$ \\
\hline $\mathrm{T}$ & Water temperature & ${ }^{\circ} \mathrm{C}$ \\
\hline $\mathrm{Q}_{\mathrm{c}}$ & Proportional increase in feeding rate per $10^{\circ}$ temperature increase & -- \\
\hline$f_{s}$ & Proportion of intake or surplus intake allocated to growth of structural tissue & -- \\
\hline $\mathrm{f}_{\mathrm{s}}$ & Normal structural tissue proportion of body weight & -- \\
\hline$\theta$ & \multicolumn{2}{|c|}{ Slope parameter for decreasing allocation to structural tissue as $\mathrm{W}_{\mathrm{s}} / \mathrm{W}$ varies around $\mathrm{f}_{\mathrm{s}}$} \\
\hline $\mathrm{W}_{\infty}$ & \multicolumn{2}{|c|}{ Body weight at which allocation to skeletal growth declines to zero } \\
\hline $\mathrm{R}_{\mathrm{i}}$ & \multicolumn{2}{|c|}{ Relative size of individual i at all ages, as a multiple of population mean size } \\
\hline$\sigma_{\mathrm{R}}^{2}$ & \multicolumn{2}{|c|}{ Variance of Ri among individuals (square of $\mathrm{CV}$ of individual $\mathrm{L}_{\infty}$ values) } \\
\hline
\end{tabular}

\section{Appendix B. Parameter Symbols, Initial Value and Prior Bounds}

\begin{tabular}{|c|c|c|c|}
\hline Parameter & Description & Initial Value (Prior Bounds) & Units \\
\hline \hline$a$ & Intercept coefficient of length-weight relationship & $1.0 \mathrm{e}^{-5}$ & $\mathrm{~g} \mathrm{~mm}^{-\mathrm{b}}$ \\
\hline$b$ & Power coefficient of length-weight relationship & 3.0 & - \\
\hline$H$ & Net food consumption rate per $\mathrm{W}^{-\mathrm{d}}$ & 1.41 \\
$(0.61-6.087)$ & 0.665 \\
$\mathrm{~g} \mathrm{~g}^{-1} \mathrm{yr}^{-1}$ \\
$m$
\end{tabular}


Appendix B. contd...

\begin{tabular}{|c|c|c|c|}
\hline Parameter & Description & Initial Value (Prior Bounds) & Units \\
\hline$d$ & Food consumption power parameter & $\begin{array}{c}0.63 \\
(0.5-1.0)\end{array}$ & - \\
\hline$n$ & Metabolism power parameter & $\begin{array}{c}0.77 \\
(0.5-1.0)\end{array}$ & - \\
\hline$Q_{c}$ & Proportional increase in feeding rate per $10^{\circ} \mathrm{C}$ temperature increase & $\begin{array}{c}2.82 \\
(1.0-7.2)\end{array}$ & - \\
\hline$Q_{m}$ & Proportional increase in metabolism per $10^{\circ} \mathrm{C}$ temperature increase & $\begin{array}{c}8.19 \\
(1.0-14.0)\end{array}$ & - \\
\hline$\theta$ & $\begin{array}{l}\text { Slope parameter for decreasing allocation to structural tissue as } W_{s} / W \\
\text { varies around } f_{s}^{*}\end{array}$ & $\begin{array}{c}0.2 \\
(0.199-0.20)\end{array}$ & - \\
\hline$g$ & Steepness parameter for decrease in feeding at high temperatures & 0.25 & ${ }^{\circ} \mathrm{C}^{-1}$ \\
\hline$T_{m}$ & Water temperature at which feeding drops by half & 24 & ${ }^{\circ} \mathrm{C}$ \\
\hline$T_{\max }$ & Maximum water temperature & 18.5 & ${ }^{\circ} \mathrm{C}$ \\
\hline$T_{\text {mean }}$ & Value at inflection point of temperature sine wave & 4.8 & ${ }^{\circ} \mathrm{C}$ \\
\hline$T_{\text {winter }}$ & Mean winter temperature & 3.2 & ${ }^{\circ} \mathrm{C}$ \\
\hline$T_{\Delta}$ & Offset for temperature sine wave & 0.67 & Year \\
\hline$C V_{L}$ & Coefficient of variation of individual maximum body lengths & 0.4 & \\
\hline$\sigma_{m}$ & Measurement error standard deviation for $\mathrm{L}_{1}$ and $\mathrm{L}_{2}$ & 8.0 & $\mathrm{~mm}$ \\
\hline
\end{tabular}

\section{REFERENCES}

[1] Steigenberger LW. Observations on the predation by squawfish (Ptychocheilus oregonense) on sockeye salmon (Onchorhynchus nerka), with particular reference to Cultus Lake, Masters thesis Columbia: University of British Columbia British, 1966.

[2] Steigenberger LW, Larkin PA. Feeding activity and rates of digestion of northern squawfish (Ptychocheilus oregonensis). J Fish Res Board Can 1974; 31: 411-20.

[3] Ricker WE. The consumption of young sockeye salmon by predaceous fish. J Fish Res Board Can 1941; 5: 293-313.

[4] Petersen JH, Ward DL. Development and corroboration of a bioenergetics model for northern pikeminnow feeding on juvenile salmonids in the columbia river. Trans Am Fish Soc 1999; 128: 784-801.

[5] Beamesderfer RCP, Ward DL, Nigro AA. Evaluation of the biological basis for a predator control program on northern squawfish (Ptychocheilus oregonensis) in the Columbia and Snake rivers. Can J Fish Aquat Sci 1996; 53: 2898-908.

[6] Kirn RA, Ledgerwood RD, Nelson RA. Digestive tract evacuation in northern squawfish (Ptychocheilus oregonensis). Can J Fish Aquat Sci 1988; 45: 548-53.

[7] Petersen JH, Kitchell JF. Climate regimes and water temperature changes in the Columbia River: bioenergetic implications for predators of juvenile salmon. Can J Fish Aquat Sci 2001; 58: 183141.

[8] Peterson JH, Gadomski MD, Thomas P. Differential predation by northern squawfish (Ptychocheilus oregonensis) on live and dead salmonids in the Bonneville Dam tailrace (Columbia River). Can J Fish Aquat Sci 1994; 51: 1197-204.

[9] Rieman BE, Beamesderfer RC. Dynamics of a northern squawfish population and the potential to reduce predation on juvenile salmonids in a Columbia River reservoir. N Am J Fish Manag 1990; 10: 228-41.

[10] Shively RS, Poe TP, Sauter ST. Feeding response by northern squawfish to a hatchery release of juvenile salmonids in the Clearwater River, Idaho. Trans Am Fish Soc 1996; 125: 230-6.
[11] Cech JJ, Castleberry DT, Hopkins TE, Peterson JH. Northern squawfish, Ptychocheilus oregonensis, O-2 consumption rate and respiration model - effects of temperature and body size. Can J Fish Aquat Sci 1994; 51: 8-12.

[12] Vigg S, Burley CC. Temperature-dependent maximum daily consumption of juvenile salmonids by northern squawfish (Ptychocheilus oregonensis ) from the Columbia River. Can J Fish Aquat Sci 1991; 48: 2491-8.

[13] Vigg S, Poe TP, Prendergrast LA, Hansel HC. Rates of consumption of juvenile salmonids and alternative prey fish by northern squawfish, walleyes, smallmouth bass, and channel catfish in JohnDay-Reservoir, Columbia River. N Am J Fish Manage 1991: 42138 .

[14] Petersen JH, Deangelas DL, Paukert CP. An overview of methods for developing bioenergetic and life history models for rare and endangered species. Trans Am Fish Soc 2008; 137: 244-53.

[15] Ney J. Bioenergetics modeling today: growing pains on the cutting edge. Trans Am Fish Soc 1993; 122: 736-48.

[16] Lantry BF, Rudstam LG, Forney JL, et al. Comparisons between consumption estimates from bioenergetics simulations and field measurements for walleyes from oneida lake, New York. Trans Am Fish Soc 2008; 137: 1406-21.

[17] Hartman KJ, Brandt SB. Systematic sources of bias in a bioenergetics model - examples for age-0 striped bass. Trans Am Fish Soc 1993; 122: 912-26.

[18] Guenard G, Boisclair D, Ugedal O, Forseth T, Jonsson B. Comparison between activity estimates obtained using bioenergetic and behavioural analyses. Can J Fish Aquat Sci 2008; 65: 1705-20.

[19] Chipps SR, Wahl DH. Bioenergetics modeling in the $21^{\text {st }}$ century: Reviewing new insights and revisiting old constraints. Trans Am Fish Soc 2008; 137: 298-313.

[20] Burke BJ, Rice JA. A linked foraging and bioenergetics model for southern flounder. Trans Am Fish Soc 2002; 131: 120-31.

[21] Taylor NG, Walters CJ, Martell SJD. A new likelihood for simultaneously estimating the von Bertalanffy growth parameters, vulnerability, natural mortality and fishing mortality. Can J Fish Aquat Sci $2005 ; 62: 215-23$. 
[22] Walters C, Essington TE. Recovery of bioenergetics parameters from information on growth. J Fish Sci 2010; 3: 52-68.

[23] Clarke A, Johnston NM. Scaling of metabolic rate with body mass and temperature in teleost fish. J Anim Ecol 1999; 68: 893-905.

[24] Beamesderfer R. Reproduction and early life history of northern squawfish, Ptychocheilus oregonensis, in Idaho's St. Joe River. Environ Biol Fish 1992; 35: 231-41.
[25] Jones W, Gurney W, Speirs D, Bacon P, Youngson A. Seasonal patterns of growth, expenditure and assimilation in juvenile Atlantic salmon. J Anim Ecol 2002; 71: 916-24.

[26] Fabens AJ. Properties and fitting of the von Bertalanffy growth curve. Growth $1965 ; 29: 265-89$

Received: May 25, 2009

(C) Taylor and Walters; Licensee Bentham Open.

This is an open access article licensed under the terms of the Creative Commons Attribution Non-Commercial License (http://creativecommons.org/licenses/by-nc/3.0/) which permits unrestricted, non-commercial use, distribution and reproduction in any medium, provided the work is properly cited. 